\title{
Analysis of the origin of Turner's syndrome using polymorphic DNA probes
}

\author{
S A R Loughlin, A Redha, J McIver, E Boyd, A Carothers, J M Connor
}

\begin{abstract}
Thirty-four families with a child or fetus with Turner's syndrome were studied using a series of polymorphic DNA probes. Analysis of the origin of the normal $\mathbf{X}$ chromosome was possible in all cases. In 16 families with 45,X (four fetuses and 12 livebirths), the observed $X$ was maternal in each case, indicating a preferential loss of the paternal sex chromosome at, or before, conception. In the remaining 18 families with a variety of karyotypes, but especially in those where the child had an isochromosome of $\mathrm{Xq}$ or a ring $\mathrm{X}$, there was again a strong tendency for the normal $X$ to be maternal. Analysis of parental ages was performed with known origin of each abnormality, but no evidence for an increased or decreased parental age effect was detected.
\end{abstract}

Turner's syndrome is one of the most common chromosomal abnormalities with an estimated frequency at conception of $1.5 \%$. Most affected fetuses are, however, spontaneously aborted and the residual birth frequency is 1 in 2500 to 5000 females. ${ }^{1}$ In a large consecutive study the majority of fetuses were found to have monosomy $X(45, X)$ with $45, X / 46, X X$ in the remainder, whereas in the same study, among liveborn Turner's syndrome patients, $53 \%$ were $45, X$, $14 \cdot 8 \%$ were mosaic $45, \mathrm{X} / 46, \mathrm{XX}, 9 \%$ were $46, \mathrm{Xi}(\mathrm{Xq}) /$ $45, \mathrm{X}, 4.9 \%$ were mosaic $47, \mathrm{XXX} / 45, \mathrm{X}$, and the remaining $9 \cdot 7 \%$ showed five other karyotypes (46,XXq-, 46,XXp-, mosaic 46,XX/45,X, + frag, mosaic $45, \mathrm{X} / 46, \mathrm{Xr}(\mathrm{X})$, and mosaic $48, \mathrm{XXXX} / 45, \mathrm{X}){ }^{2}$

Early analyses of the origin of Turner's syndrome used the Xg blood group, but these studies were not

University Department of Medical Genetics, Duncan Guthrie Institute, Yorkhill, Glasgow G3 8SJ.

S A R Loughlin, A Redha, J McIver, E Boyd, J M Connor

MRC Human Genetics Unit, Western General Hospital, Edinburgh EH4 2XU.

A Carothers

Correspondence to Professor Connor.

Received for publication 7 August 1990.

Revised version accepted for publication 12 November 1990. applicable to cultured cells from affected fetuses, were only informative in a proportion (31\%) of families, and were biased in that informative families were more frequent for $45, \mathrm{X}^{\mathrm{m}}$ than for $45, \mathrm{X}^{\mathrm{P}} .{ }^{4}$ The development of multiple polymorphic DNA markers for the $\mathrm{X}$ chromosome offers an alternative approach which should avoid these difficulties. Hassold $e t a l^{56}$ used this alternative approach to study $\mathbf{4 0}$ families with Turner's syndrome where the majority were spontaneously aborted fetuses, and were able to identify the parental origin in $35(88 \%)$ of their families. We describe our results from a study of 34 families in which the majority were live born and where the origin of the abnormality has been determined for a variety of karyotypic abnormalities.

Patients and methods

ASCERTAINMENT OF CASES

Families for this study were recruited from the records of the West of Scotland Regional Genetics Service and with the assistance of the United Kingdom Child Growth Foundation.

\section{CYTOGENETIC ANALYSIS}

Chromosomal analysis was undertaken using standard cytogenetic techniques on peripheral blood lymphocytes or cultured products of conception. Two families where the proband had Turner's syndrome but $45, \mathrm{X} / 46, \mathrm{XY}$ (that is, a paternal defect) were excluded from DNA analysis.

\section{DNA ANALYSIS}

DNA was extracted from cultured fetal cells in the case of an affected fetus or from peripheral blood lymphocytes of affected children and of both parents. DNA samples were digested with the appropriate restriction enzymes under the conditions specified by the manufacturers. The resulting fragments were fractionated on $0.8 \%$ agarose gels and Southern blotted onto Hybond-N (Amersham) followed by hybridisation with radiolabelled DNA probes. The probes used were St14.1 (DXS52), L1.28 (DXS7), XJ1.1 (DXS206), p198 (MIC2), L754 (DXS84), pERT87.1 (DXS164), p99.6 (DXS41), F8C, 781 
Table 1 Parental origin of the normal X chromosome.

\begin{tabular}{|c|c|c|c|c|c|}
\hline Ped No & $\underset{\text { stat }}{\text { Clin }}$ & $\begin{array}{l}\text { Mat } \\
\text { age }\end{array}$ & $\begin{array}{l}\text { Pat } \\
\text { age }\end{array}$ & Karyotype & $\begin{array}{c}\text { Parental origin of } \\
\text { normal } \mathrm{X} \text { (informative probe) }\end{array}$ \\
\hline $\begin{array}{l}7751 \\
7376 \\
7780 \\
7962 \\
1125 \\
2395 \\
4278 \\
4769 \\
5212 \\
8437 \\
9018 \\
9020 \\
9039 \\
9051 \\
9447 \\
9533 \\
0618 \\
9378 \\
3515 \\
7398 \\
9019 \\
9029 \\
9288 \\
1241 \\
1349 \\
3171 \\
3927 \\
5879 \\
8438 \\
9017 \\
9316 \\
3805 \\
9401 \\
3517\end{array}$ & $\begin{array}{l}\text { F } \\
\text { F } \\
\text { F } \\
\text { F } \\
\text { LB } \\
\text { LB } \\
\text { LB } \\
\text { LB } \\
\text { LB } \\
\text { LB } \\
\text { LB } \\
\text { LB } \\
\text { LB } \\
\text { LB } \\
\text { LB } \\
\text { LB } \\
\text { LB } \\
\text { LB } \\
\text { LB } \\
\text { LB } \\
\text { LB } \\
\text { LB } \\
\text { LB } \\
\text { LB } \\
\text { LB } \\
\text { LB } \\
\text { LB } \\
\text { LB } \\
\text { LB } \\
\text { LB } \\
\text { LB } \\
\text { LB } \\
\text { LB } \\
\text { LB }\end{array}$ & $\begin{array}{l}24 \cdot 4 \\
\text { NA } \\
19 \cdot 3 \\
27 \cdot 5 \\
27 \cdot 5 \\
33 \cdot 7 \\
\text { NA } \\
23 \cdot 4 \\
31 \cdot 5 \\
37 \cdot 6 \\
27 \cdot 5 \\
33 \cdot 5 \\
17 \cdot 7 \\
26 \cdot 9 \\
\text { NA } \\
\text { NA } \\
28 \cdot 7 \\
22 \cdot 5 \\
22 \cdot 3 \\
29 \cdot 8 \\
25 \cdot 3 \\
26 \cdot 8 \\
30 \cdot 3 \\
30 \cdot 5 \\
20 \cdot 5 \\
27 \cdot 7 \\
22 \cdot 5 \\
32 \cdot 7 \\
24 \cdot 2 \\
26 \cdot 6 \\
\text { NA } \\
19 \cdot 4 \\
31 \cdot 3 \\
26 \cdot 7\end{array}$ & $\begin{array}{l}25 \cdot 8 \\
\text { NA } \\
\text { NA } \\
30 \cdot 7 \\
28 \cdot 5 \\
34 \cdot 2 \\
\text { NA } \\
25 \cdot 7 \\
29 \cdot 5 \\
41 \cdot 7 \\
26 \cdot 3 \\
34 \cdot 1 \\
\text { NA } \\
30 \cdot 3 \\
\text { NA } \\
\text { NA } \\
29 \cdot 2 \\
27 \cdot 6 \\
25 \cdot 2 \\
28 \cdot 9 \\
26 \cdot 8 \\
30 \cdot 5 \\
35 \cdot 6 \\
28 \cdot 5 \\
23 \cdot 5 \\
30 \cdot 3 \\
24 \cdot 3 \\
36 \cdot 1 \\
26 \cdot 5 \\
24 \cdot 6 \\
\text { NA } \\
23 \cdot 3 \\
30 \cdot 4 \\
26 \cdot 7\end{array}$ & 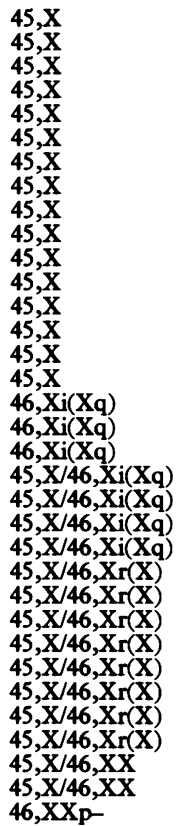 & $\begin{array}{l}\text { Maternal (St14.1) } \\
\text { Maternal (St14.1) } \\
\text { Maternal (St14.1) } \\
\text { Maternal (St14.1) } \\
\text { Maternal (St14.1) } \\
\text { Maternal (St14.1) } \\
\text { Maternal (St14.1) } \\
\text { Maternal (St14.1) } \\
\text { Maternal (St14.1) } \\
\text { Maternal (St14.1) } \\
\text { Maternal (St14.1) } \\
\text { Maternal (St14.1) } \\
\text { Maternal (St14.1) } \\
\text { Maternal (St14.1) } \\
\text { Maternal (St14.1) } \\
\text { Maternal (754) } \\
\text { Maternal (p19B) } \\
\text { Maternal (St14.1) } \\
\text { Paternal (St14.1) } \\
\text { Paternal (87.1) } \\
\text { Maternal (St14.1) } \\
\text { Maternal (St14.1) } \\
\text { Maternal (p20) } \\
\text { Paternal (782) } \\
\text { Paternal (XJ1.1) } \\
\text { Maternal (St14.1) } \\
\text { Maternal (St14.1) } \\
\text { Maternal (L128) } \\
\text { Maternal (99.6) } \\
\text { Maternal (F8A) } \\
\text { Maternal (F8A) } \\
\text { Paternal (St14.1) } \\
\text { Paternal (St14.1) } \\
\text { Paternal (754) }\end{array}$ \\
\hline
\end{tabular}

$\mathrm{NA}=$ not available, $\mathrm{F}=$ fetus, $\mathrm{LB}=$ livebirth.

(DXS120), and p20 (DXS324). ${ }^{7}$ The initial screening was performed using St14.1. Those families uninformative with this probe, or with chromosomal rearrangements, were subsequently screened with further short and long arm probes. In addition, the cytogenetically non-mosiac patients were screened with Y chromosome specific probes, GMGY1 (DYS12) which maps to the long arm of the $\mathrm{Y}$ chromosome, and GMGY7 (DYS58) which is a short arm probe.

\section{PARENTAL AGE ANALYSIS}

Parental ages were compared with those of the Scottish population as follows. For each maternal age, its residual was computed as: (maternal age-mean maternal age in population)/(standard deviation of maternal age in population) where the population means and standard deviations were computed from the published tables of the Registrar General Scotland for the corresponding year of birth. The method therefore allows for fluctuations in the population parental age distributions over the period of the study. Under the null hypothesis that the maternal ages of cases are a random sample from the population, the residuals have an expected mean of zero, and an expected standard deviation of 1 , so that conventional tests can be applied. Paternal ages were treated similarly. The parental ages of fetuses were incremented by 0.5 years to correspond (approximately) to expected dates of delivery.

\section{Results}

The parental origin of the normal $\mathrm{X}$ chromosome was determined in all families studied (table 1). This table includes 27 families briefly described previously. ${ }^{8}$ Overall there were 27 subjects $(79 \cdot 4 \%)$ in which the normal $X$ was maternally derived $\left(X^{m}\right)$ and seven $(20.6 \%)$ with a paternally derived $X\left(X^{p}\right)$. In this study children (12) and fetuses (four) with 45,X always had a maternal $X$, indicating loss of a paternal sex chromosome at, or before, conception. This maternal excess was also present, albeit less marked, for the other karyotypes found in liveborn Turner's syndrome patients. For isochromosome $\mathrm{Xq}$ (mosaic and non-mosaic), the normal $X$ was maternal in five and paternal in two and for ring $X$ the normal $X$ was maternal in six and paternal in two. Maternal and paternal ages were available for 29 and 27, respectively, and gave mean residuals of 0.03 years and 0.01 years, not significantly different from the zero values expected under the null hypothesis. No significant 
Table 2 Analysis of the origin of Turner's syndrome using polymorphic DNA probes.

\begin{tabular}{lccl}
\hline & $\begin{array}{c}\text { Normal X } \\
\text { paternal } \\
\left(X^{\mathrm{p}}\right)\end{array}$ & $\begin{array}{c}\text { Normal X } \\
\text { maternal } \\
\left(X^{\mathrm{m}}\right)\end{array}$ & \multicolumn{1}{c}{ Reference } \\
\hline 45,X children & 1 & 4 & 56 \\
& 9 & 20 & 9 \\
Total & 7 & 14 & 10 \\
45,X fetuses & 0 & 12 & Present study \\
Total & 17 & 50 & \\
46,Xi(Xq) & 6 & 24 & 56 \\
& 0 & 4 & Present study \\
Total & 6 & 28 & \\
$45, X / 46, X i(X q)$ & 3 & 2 & 11 \\
Total & 6 & 2 & 12 \\
$45, X / 46, X X$ & 1 & 2 & Present study \\
45,X/46,r(X) & 10 & 6 & \\
Total & 1 & 4 & 9 \\
46,XXp- & 4 & 3 & Present study \\
\hline
\end{tabular}

deviations from the null values were obtained when the families were grouped by karyotype or by parental origin, though in most groups the numbers were insufficient to give much force to this conclusion. The use of several $\mathrm{X}$ polymorphic probes and $\mathrm{Y}$ specific probes (but not $\mathrm{X}$ or $\mathrm{Y}$ centromeric probes) in cytogenetically non-mosaic patients did not show any evidence for cryptomosaicism.

\section{Discussion}

The utility of DNA analysis for the investigation of sex chromosome abnormality was shown in this study where the origin of the normal $\mathrm{X}$ was determined in every family. Table 2 compares our findings with those of others using DNA analysis. Overall, using DNA analysis, in 45,X (fetuses and livebirths) the normal $X$ is maternal in $77 \cdot 2 \%$. For fetuses with $45, X, 82 \cdot 4 \%$ have $X^{m}$ and for livebirths $74 \cdot 6 \%$ have $\mathrm{X}^{\mathrm{m}}$, a difference which is not statistically significant $\left(\chi^{2}=0 \cdot 76\right)$. The comparable figures derived using $\mathrm{Xg}$ studies in 80 informative liveborn females with Turner's syndrome and corrected for bias were $77 \%$ $\mathrm{X}^{\mathrm{m}}$ and $23 \% \mathrm{X}^{\mathrm{p} .{ }^{34}}$ Non-disjunction at paternal meiosis could account for the high number of apparently non-mosaic $45, X$ subjects with no paternal sex chromosome but this is not reflected in the frequency of sperm with no sex chromosome, ${ }^{13} 14$ nor with a frequency of $47, \mathrm{XXY}$ and $47, \mathrm{XXX}$ comparable with Turner's syndrome in early pregnancy. A preponderance of paternal sex chromosome loss has also been found in comparable studies into the origin of $39, \mathrm{X}$ mice and these errors are attributable to loss of the paternal $\mathrm{X}$ or $\mathrm{Y}$ following entry of the sperm into the egg. ${ }^{15}$ The human paternal sex chromosome could also be lost at this stage to result in $45, X$. Later loss during an embryonic mitotic cell division would produce the most common type of mosaicism in both fetuses and live births with Turner's syndrome $(45, \mathrm{X} / 46, \mathrm{XX})$. Overall for other karyotypes, using DNA analysis, the normal $\mathrm{X}$ is maternal in $52 \%$ but the numbers for individual karyotypes are still relatively small.

We wish to thank the Child Growth Foundation for their assistance in recruiting patients for this study and also the patients, their parents, and their clinicians.

1 Jacobs PA. The load due to chromosome abnormalities in man. In: Salzano FM, ed. The role of natural selection in human evolution. Amsterdam: North-Holland, 1975:337-52.

2 Hook EB, Warburton D. The distribution of chromosomal genotypes associated with Turner's syndrome: livebirth prevalence rates and evidence for diminished fetal mortality and severity in genotypes associated with structural $\mathrm{X}$ abnormalities or mosaicism. Hum Genet 1983;64:24-7.

3 Sanger R, Tippett $\mathbf{P}$, Gavin J. Xg groups and sex abnormalities in people of North European ancestry. $\mathcal{F}$ Med Genet 1971;8:417-26.

4 Fraser GR. Parental origin of the sex chromosomes in the XO and XXY karyotypes in man. Ann Hum Genet 1963;26:297-304. Corrigenda and addendum. Ann Hum Genet 1965;29:323.

5 Hassold T, Kumlin E, Takaesu N, Leppert M. Determination of the parental origin of sex chromosome monosomy using restriction fragment length polymorphisms. Am $\mathcal{f}$ Hum Genet 1985;37:965-72.

6 Hassold T, Benham F, Leppert M. Cytogenetic and molecular analysis of sex chromosome monosomy. Am $\mathcal{F}$ Hum Genet 1988;42:534-41.

7 Kidd KK, Bowcock AM, Schmidtke J, et al. Report of the DNA committee and catalogs of cloned and mapped genes and DNA polymorphisms. Cytogenet Cell Genet 1989;51:622-47.

8 Connor JM, Loughlin SAR. Molecular genetics of Turner's syndrome. Acta Paediatr. Scand [Suppl] 1989;356:77-80.

9 Jacobs PA, Betts PR, Cockwell AE, et al. A cytogenetic and molecular reappraisal of a series of patients with Turner's syndrome. Ann Hum Genet 1990;54:209-23.

10 Lippe BM, Stekol L, Mathur A, Maclaren NK, Scott ML. Phenotypic and physiologic characterisation of Turner syndrome: a preliminary study of the relationship to parental origin of the $\mathbf{X}$ chromosome. In: Ranke $M$, Rosenbloom $\mathrm{K}$, eds. Turner syndrome. Amsterdam: Elsevier (in press).

11 Callen DF, Mulley JC, Baker EG, Sutherland GR. Determining the origin of human $X$ isochromosomes by use of DNA sequence polymorphisms and detection of an apparent $\mathrm{i}(\mathrm{Xq})$ with Xp sequences. Hum Genet 1987;77:236-40.

12 Harbison M, Hassold T, Kobryn C, Jacobs PA. Molecular studies of the parental origin and nature of human $\mathrm{X}$ isochromosomes, Cytogenet Cell Genet 1988;47:217-22.

13 Martin RH, Balkan W, Burns K, Rademaker AW, Lin CC, Rudd NL. The chromosome constitution of 1000 human spermatozoa. Hum Genet 1983;63:305-9.

14 Brandriff B, Gordon L, Ashworth L, Watchmaker G, Carrano A, Wyrobek A. Chromosomal abnormalities in human sperm: comparisons among four healthy men. Hum Genet 1984;66: 193-201.

15 Russell LB, Montgomery CS. The incidence of sex-chromosome anomalies following irradiation of mouse spermatogonia with single or fractionated doses of X-rays. Mutat Res 1974;25: 367-76. 